\title{
Comparison of Equivalent Linear and Non Linear Methods on Ground Response Analysis: Case Study at West Bangka Site
}

\author{
Eko Rudi Iswanto*1, Eric Yee ${ }^{2}$ \\ ${ }^{1}$ Pusat Kajian Sistem Energi Nuklir-BATAN \\ Jl. Kuningan Barat, Mampang Prapatan, Jakarta 12710, Indonesia \\ ${ }^{2}$ International Nuclear Graduate School, KEPCO \\ Seosaeng-myeon Ulju-gun, Ulsan 689-882, South Korea
}

\begin{tabular}{l}
\hline ARTICLE INFORM ATION \\
\hline Article History: \\
Received: \\
02 August 2016 \\
Received in revised form: \\
27 September 2016 \\
Accepted: \\
1 October 2016
\end{tabular}

Keywords:

Bangka site

Ground response

\begin{abstract}
COMPARISON OF EQUIVALENT LINEAR AND NON LINEAR METHODS ON GROUND RESPONSE ANALYSIS: CASE STUDY AT WEST BANGKA SITE. Within the framework of identifying NPP sites, site surveys are performed in West Bangka (WB), Bangka-Belitung Island Province. Ground response analysis of a potential site has been carried out using peak strain profiles and peak ground acceleration. The objective of this research is to compare Equivalent Linear (EQL) and Non Linear (NL) methods of ground response analysis on the selected NPP site (West Bangka) using DeepSoil software. Equivalent linear method is widely used because requires soil data in simple way and short time of computational process. On the other hand, non linear method is capable of representing the actual soil behaviour by considering non linear soil parameter. The results showed that EQL method has similar trends to NL method. At surface layer, the acceleration values for EQL and NL methods are resulted as $0.425 \mathrm{~g}$ and $0.375 \mathrm{~g}$ respectively. NL method is more reliable in capturing higher frequencies of spectral acceleration compared to EQL method.

ABSTRAK

PERBANDINGAN METODE EKUIVALEN LINIER DAN NON LINIER PADA ANALISIS GROUND RESPONSE: STUDI KASUS TAPAK BANGKA BARAT. Dalam mengidentifikasi tapak PLTN, survey tapak dilakukan di Bangka Barat. Analisis ground response tapak potensial telah dilakukan menggunakan profil peak strain dan percepatan tanah puncak. Tujuan penelitian adalah untuk membandingkan metode EQL dan NL pada analisis ground response di tapak PLTN terpilih (Bangka Barat) menggunakan perangkat lunak DeepSoil. Metode Ekuivalen Linier digunakan secara luas karena data yang dibutuhkan lebih sederhana dan proses komputasi yang singkat. Di sisi lain, metode Non-Linier mampu menggambarkan kondisi tanah yang sebenarnya dengan mempertimbangkan parameter tanah yang non-linear. Hasil penelitian menunjukkan bahwa metode EQL mempunyai kecenderungan yang sama dengan metode NL. Nilai percepatan lapisan permukaan menggunakan metode EQL dan NL, masing-masing menghasilkan $0,425 \mathrm{~g}$ dan $0,375 \mathrm{~g}$. Metode $\mathrm{NL}$ mempunyai kelebihan dalam menangkap frekuensi yang lebih tinggi dari percepatan spektra dibandingkan metode EQL.

Kata Kunci: tapak Bangka, ground response
\end{abstract}

(C) 2016 Jurnal Pengembangan Energi Nuklir. All rights reserved

\section{INTRODUCTION}

Indonesia is considering building Nuclear Power Plant (NPP) by 2025. Thorough preparation and steps are needed to operate an NPP and it takes between 10 to 15 years from the preliminary study (site selection, financial study, etc.) up to project implementation (manufacturing, construction, commissioning). Within the framework of identifying NPP sites, site surveys are

${ }^{*}$ Corresponding author.

E-mail: ekorudi@batan.go.id performed in West Bangka (WB), BangkaBelitung Island Province.

The safety requirements of NPP are stringent; amongst the various requirements is the ability to safely shut down in the wake of a possible earthquake. Ground response analysis of a potential site therefore needs to be carried out using peak strain profiles and peak ground acceleration. The objective of this research is to compare Equivalent Linear (EQL) and Non Linear (NL) of ground response analysis on the selected NPP site 
(West Bangka). This analysis will be carried out using DeepSoil software[1].

\section{GROUND RESPONSE ANALYSIS}

Ground response analysis is the process of calculating the shear wave propagation due to seismic loading through borehole. The wave propagation problem is solved quantified the effect of soil deposits on propagated ground motion [2]. One dimensional ground response analysis is mainly performed using an equivalent linear (EQL) method in which the wave equation is solved in the frequency domain and a nonlinear (NL) method in which employing non-linear hysteretic soil models is solved in the time domain using numerical integration[3]. Both methods of analysis require the choice of appropriate dynamic soil properties curves for the examined materials [4]. These methods have been carried out using DeepSoil, a one-dimensional site response analysis program that can perform EQL method and NL method. It can feature a spontaneous graphical user interface and has capability of deriving a number of strong motion parameters often required for engineer.

One-dimensional analysis is based on the assumption that all boundaries are horizontal and that the response of a soil deposit is generally caused by $\mathrm{SH}$-waves propagating in the vertical direction from the underlying bedrock. The soil and bedrock surface are considered to extend infinitely in the horizontal direction.

\subsection{Equivalent Linear (EQL) Method}

The EQL method is just an approximation hysteretic behavior of soil [5]. and it consists of modififying the Kelvin-Voigt model to account for some types of soil nonlinearities [6]. The value of shear modulus and damping ratio is used to calculate the linear soil behavior then the peak strains in the soil layers are computed. An effective shear strain is then calculated for each layer by multiplying the peak shear strain by an effective shear strain ratio. This strain value is used to determine modulus reduction and damping ratio of each layer.

\subsection{Nonlinear (NL) Method}

The NL method simulates the hysteretic stress-strain response of the soil. It is capable of representing the actual behavior of soils much more accurately and more realistic than the EQL method. The soil profile can be modeled using either lumped masses or finite element. In the lumped-mass approach, the soil layers are lumped into adjacent nodal masses, which are connected by springs that model the soil stress-strain behavior in shear.

The input ground motion is applied at the base of the borehole, and the dynamic equations of motion are integrated using the Newmark $-\beta$ method in order to calculate the response of the soil layers. The hysteretic material models are characterized by (1) the backbone curve, and (2) a set of hysteresis rules. A theoretical model in that the initial loading curve (backbone curve) as a hyperbolic line is developed from the hysteresis rules [5].

The NL method is capable of representing the actual behaviour of soils much more accurately and more realistic than the EQL method. When performing fully nonlinear analyses, shear modulus and damping ratio vary throughout the duration of loading [7]. The family of hyperbolic soil models are often used use in order to represent backbone curve which defined as stress-strain relationship [8]. As loading, a sudden stress will cause numerical instabilities, therefore smaller time interval should be taken [9].

\subsection{Dynamic Soil Properties And Material Modeling For Analysis}

Site response analysis is performed using a maximum frequency. The maximum frequency is the highest frequency that the layer can propagate and is calculated by the equation:

$\mathrm{f}_{\max }=\frac{\mathrm{V}_{\mathrm{s}}}{4 \mathrm{H}}$

where $V_{S}$ is the shear wave velocity of the layer, and $\mathrm{H}$ is the thickness of the layer. To increase the maximum frequency, the thickness of the layer should be decreased. 
For all layers, the maximum frequency should fall between a range of a minimum of $25 \mathrm{~Hz}$ and a maximum of $50 \mathrm{~Hz}$.

Soil exhibit nonlinear behavior, a hyperbolic relationship can be used to relate the shear stress and shearing strain in modeling dynamic soil behavior[7]. In DeepSoil the hyperbolic model is used to define the backbone curve, which is given by the equation:

$$
\frac{\mathrm{G}}{\mathrm{G}_{\max }}=\frac{1}{1+\beta\left(\frac{\gamma}{\gamma_{\mathrm{r}}}\right)^{\alpha}}
$$

where $\frac{G}{G_{\max }}=$ modulus reduction; $\mathrm{z}=$ shear strain; $\mathrm{\gamma}_{\mathrm{r}}=$ pseudo reference strain; and $\mathrm{a}=$ 0.92 and $\beta=1$ as fitting coefficient. The pseudo reference strain describes the backbone curve at small strains $\quad(x<\sim 0.3-$ $0.5 \%$ [10]. It was predicted from empirical models by Darendeli and Menq. Darendeli developed model from a large database taking into account both plastic and non-plastic soil materials, while Menq was derived model of specifically for granular soil materials. However, the hyperbolic model breaks down at large strains, where it tends to produce biased shear strength estimation.

\section{METHODOLOGY}

The flow diagram of ground response analysis methodology is showed at Figure 1.

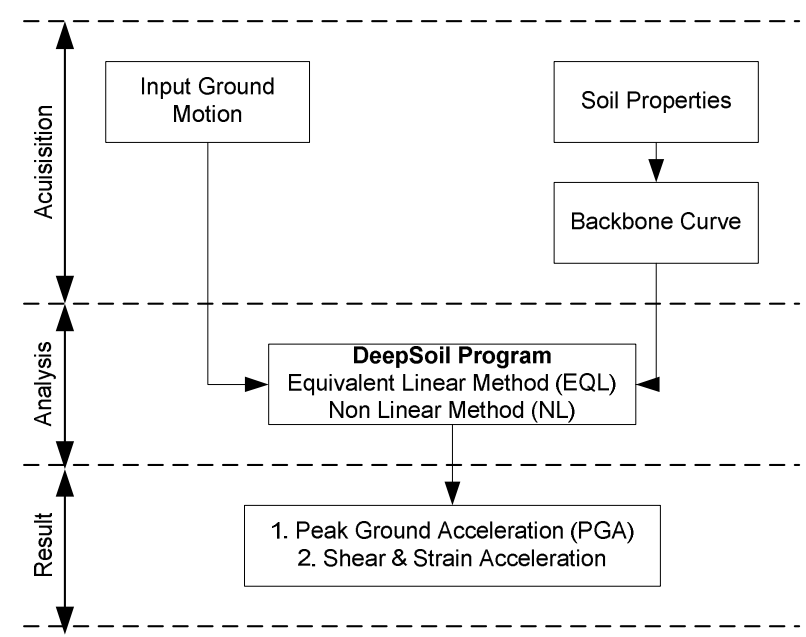

Figure 1. Flow Diagram of Ground Response Analysis

\subsection{Location}

West Bangka site is selected as the preferred area for the first NPP sites for some reasons in terms of their acceptability such as safety, suitability, and construction cost, and other considerations. WB at Bangka Island, Bangka-Belitung Island Province can be seen in Figure 2.

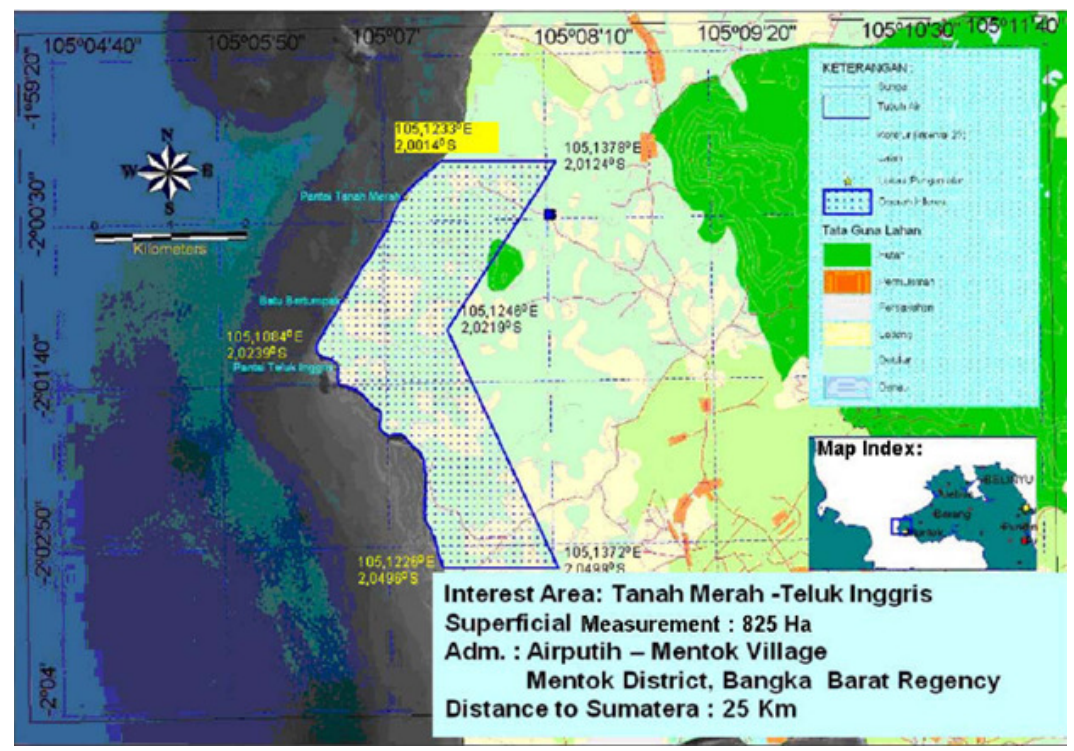

Figure 2. Map of Bangka Barat (WB), Bangka-Belitung Island Province, Indonesia[11]. 


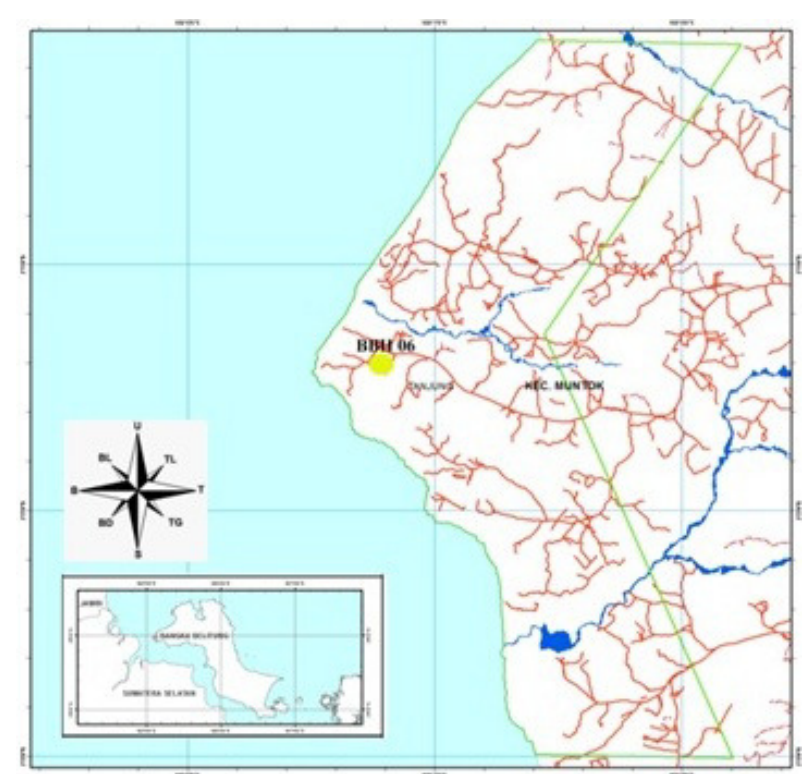

Figure 2. The Location of BBH 06 at The WB Site[11].

According to literature study and field confirmation, WB site is free from exclusions factors and therefore they can be considered as area which is potential to be developed further[11]. It has been considered as a stable area among other islands in Indonesia with relatively low seismicity and there are no significant earthquakes in this area.

\subsection{Geotechnical Data[11]}

A site exploration program was performed at WB site that included the drilling of boreholes, in-situ testing such as standard penetration testing (SPT) with energy measurements, and suspension logging of seismic velocities, and laboratory testing. In this project, geotechnical site investigation data are collected from the borehole, namely Bangka Bore Hole (BBH) 06 where the reactor will be placed. The location of BBH 06 at the WB Site is shown in the Figure 3. The borehole was drilled using rotary wash procedures with a diameter of $116 \mathrm{~mm}$ for the upper $20 \mathrm{~m}$ and a diameter of $86 \mathrm{~mm}$ thereafter.

The SPT is performed during a soil boring to obtain an approximate measure of the dynamic soil resistance. The first increment is recorded as a "seating", while the number of blows to advance the second
Table 1. Results of Index Tests[11]

\begin{tabular}{cc}
\hline Depth $(\mathrm{m})$ & SPT blow counts, N \\
\hline 3 & 13 \\
6 & 9 \\
9 & 12 \\
12 & 23 \\
15 & 52 \\
17.55 & 54 \\
20.55 & 49 \\
23.55 & 56 \\
26.55 & 58 \\
30 & $>50$ \\
\hline
\end{tabular}

and third increments are summed to give the $\mathrm{N}$-value ("blow count") or SPT-resistance (reported in blows $/ 0.3 \mathrm{~m}$ ). Table 1 shows the result of SPTs at BBH 06[11].

Geophysical methods are used in geotechnical investigations to evaluate the dynamic response of that soil by measuring a soil's shear wave velocity. For this project $\mathrm{BBH} 06$ is performed using SPT, then PS suspension logging was used to measure shear wave (S wave) and compression wave (P wave). The geologic log and the PS suspension logging of BBH 06 can be seen at Figure 4.

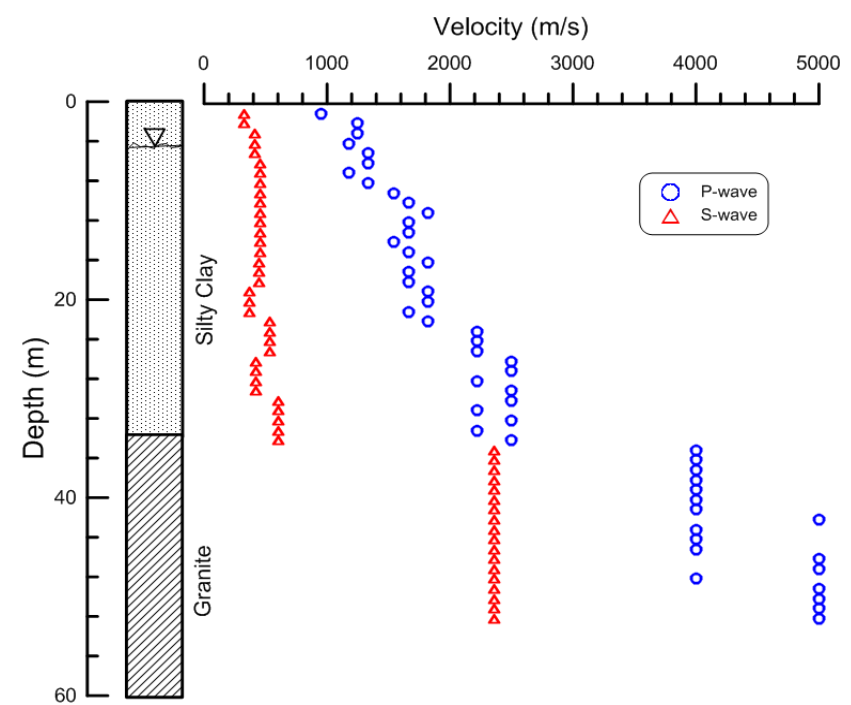

Figure 3. Geologic Log at BBH 06 and PS Logging[11]. 
Table 2. Results of Index Tests[11]

\begin{tabular}{cccccc}
\hline $\begin{array}{c}\text { Depth } \\
(\mathrm{m})\end{array}$ & $\begin{array}{c}\text { Unit Weight } \\
\left(\mathrm{kN} / \mathrm{m}^{\mathbf{3}}\right)\end{array}$ & Specific Gravity & $\begin{array}{c}\text { Water Content } \\
(\boldsymbol{\%})\end{array}$ & $\begin{array}{c}\text { Grain Size } \\
\text { Distribution (\%) }\end{array}$ & $\begin{array}{c}\text { Atterberg Limit } \\
(\boldsymbol{\%})\end{array}$ \\
\hline $0-34$ & 17.96 & $2.63-2.68$ & $27.33-29.10$ & Sand: $39.42-$ & WL: $59-71$ \\
& & & 43.12 & \\
& & & Silt: $35.6-44.88$ & Ip: $12-40$ \\
\hline
\end{tabular}

Table 3. Results of Shear Tests For BBH 06[11]

\begin{tabular}{ccc}
\hline Test & $\begin{array}{c}\text { Angle of internal } \\
\text { friction }-\boldsymbol{\phi} \\
\left({ }^{\circ}\right)\end{array}$ & $\begin{array}{c}\text { Apparent } \\
\text { cohesion- } \\
\left(\mathrm{kN} / \mathrm{m}^{2}\right)\end{array}$ \\
\hline UU Triaxial & $7-29$ & $24.52-48.05$ \\
Direct Shear & $7-29$ & $20.59-41.19$ \\
\hline
\end{tabular}

Soil samples that are collected during the drilling of borehole were tested using sieve analysis, plastic limit, specific gravity and direct shear test for physical, chemical and engineering characteristics. The results of index tests including grain size distribution, atterberg limits, and maximum and minimum unit weight and the results of direct shear tests are shown in the Table 2 and 3 respectively.

\subsection{Input Motion}

For present analysis, The Sumatra Earthquake, so called Sikuai2 with Mw 7.9 in Sikuai Island, West Sumatra on September 12, 2007 is used as input motions. This earthquake occurred off the southern coast of Sumatra about $167.7 \mathrm{~km}$ at 2.5060오,

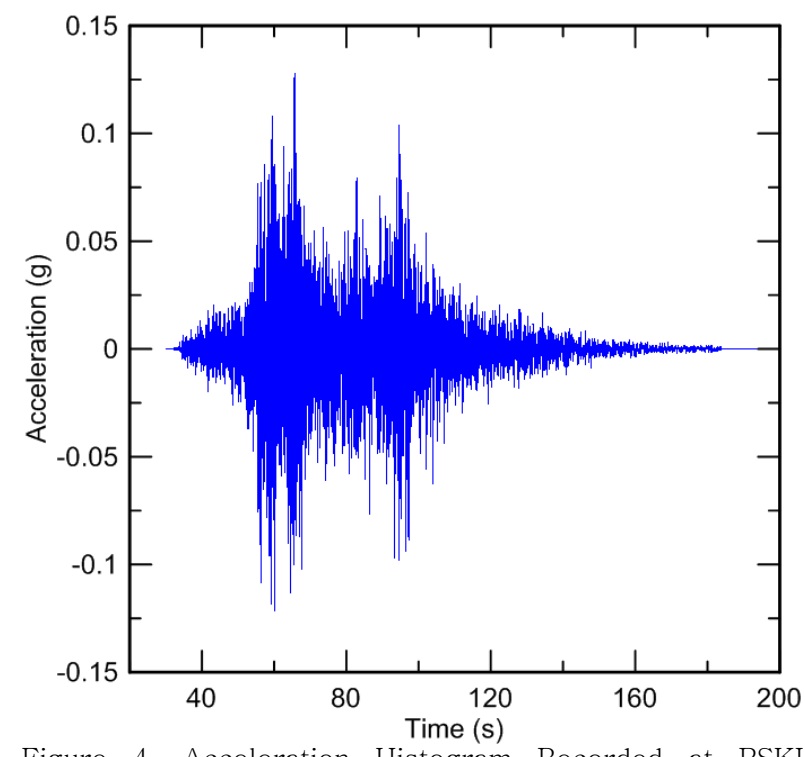

Figure 4. Acceleration Histogram Recorded at PSKI Station During Sumatra Earthquake, NS Component [11].
100.9060 oE with a depth of $30.0 \mathrm{~km}$. It has PGA value $0.13 \mathrm{~g}$. Record of accelerograph of horizontal component of input motion at PSKI station is shown at Figure 5.

\section{RESULT AND DISCUSSION}

In this paper, new values of shear strain and damping are used to generate modulus reduction and damping curve as a target curve for each layer. Then, the fitting procedure in DeepSoil is performed for each sub layer of the soil model. The new backbone curves are input into DeepSoil. The dash blue line represents the initial strength, while the solid blue line represents the strength-adjusted as shown in Figure 6.

Ground response analyses are performed for $\mathrm{BBH} 06$ subjected to the corresponding input motions, strengthadjusted backbone and damping curves using DeepSoil. Responses are presented in term of acceleration response spectra at the surface and the peak strain profiles as can be seen in Figure 7 and 8 respectively. The surface acceleration response spectra indicates the peak value of the absolute accelerations of single degree of freedom oscillators with varying frequencies of shaking [12].

Sikuai2 input motion is indicated by the solid black line, the solid red line represents acceleration response spectra for EQL method, and blue line represents acceleration response spectra for NL method at surface. Acceleration response spectra at the surface in which EQL method is $1.98 \mathrm{~g}$ and for NL method is $1.80 \mathrm{~g}$ as can be seen in Figure 7 .

The peak strain profile calculated using EQL method is close to those calculated by NL method. The peak strain profiles show many spikes through the depth of soil profile. One of the highest spikes is formed by strain in the soil layer at depth 18-20 m which has smaller shear wave velocity compare to other layers 

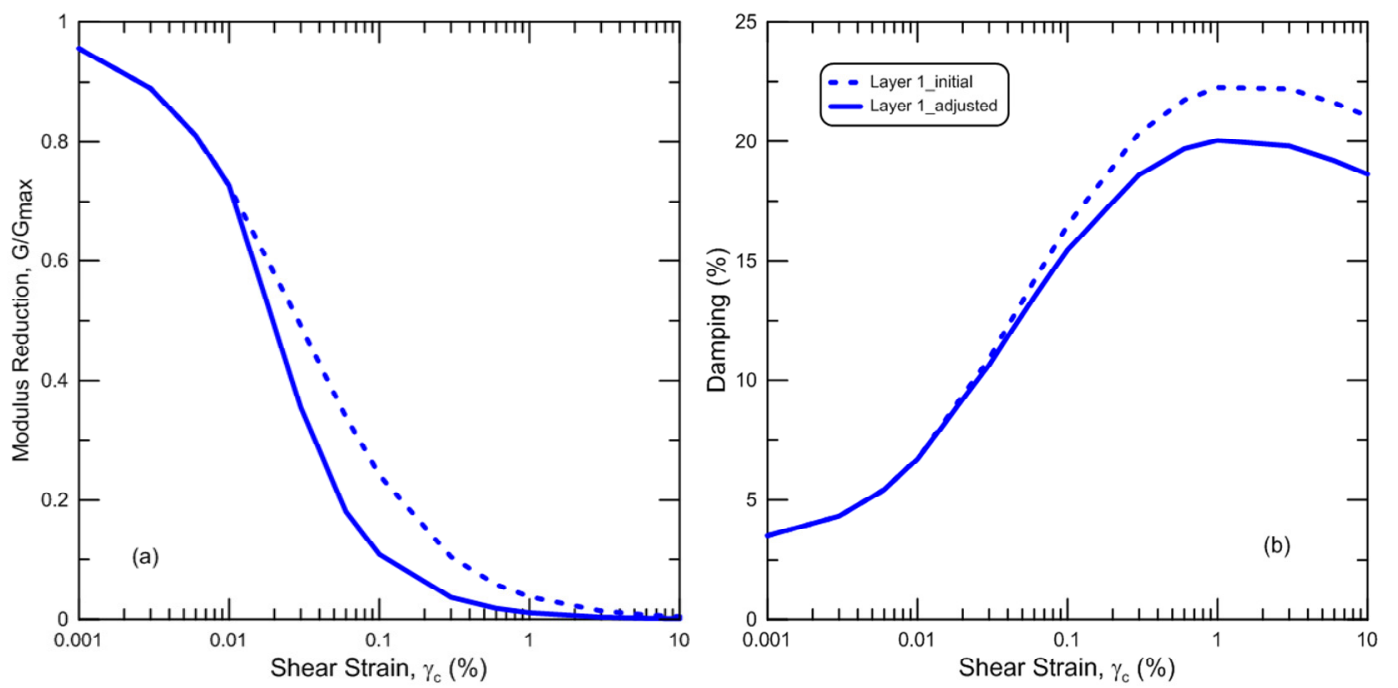

Figure 5. Comparison of The Initial and Strength-Adjusted of (a) Modulus Reduction and (b) Damping Model.

as described in Figure 8.(a). While at the surface layer, the acceleration values for EQL and NL methods are resulted as $0.425 \mathrm{~g}$ and $0.375 \mathrm{~g}$ respectively as shown in Figure 8.(b). The difference between EQL and NL responses varies with soil profile. In general, results of the analyses with EQL method show similar trends to those with NL method.

Figure 9 illustrates Fourier transforms of spectral accelerations at the surface subjected to input motion. The spectral accelerations calculated using EQL method is increasingly different at shorter period. It indicates EQL method is unable to reproduce the higher frequency response. The EQL method involves a linear analysis with a constant shear modulus for each layer. On the

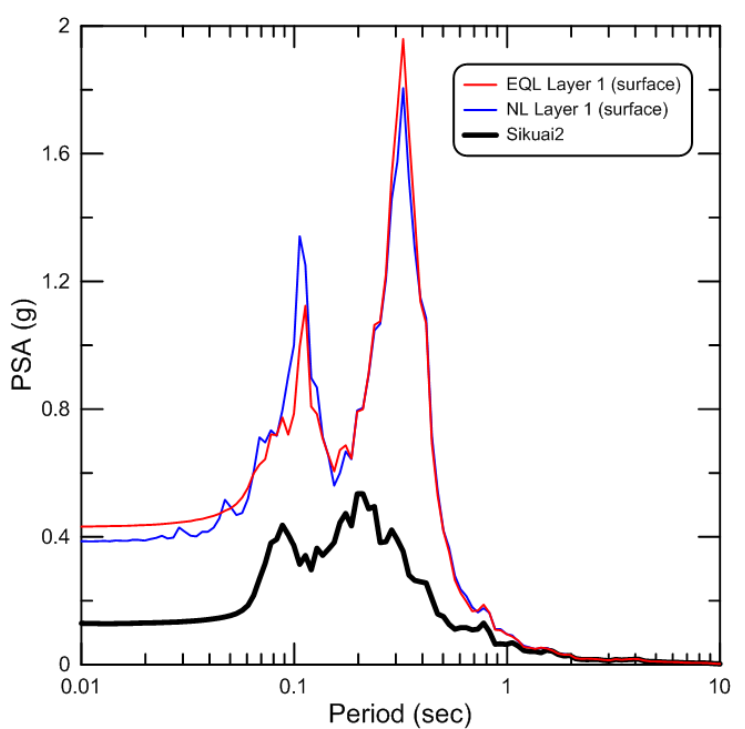

Figure 7. Surface Acceleration Response Spectra for EQL and NL.
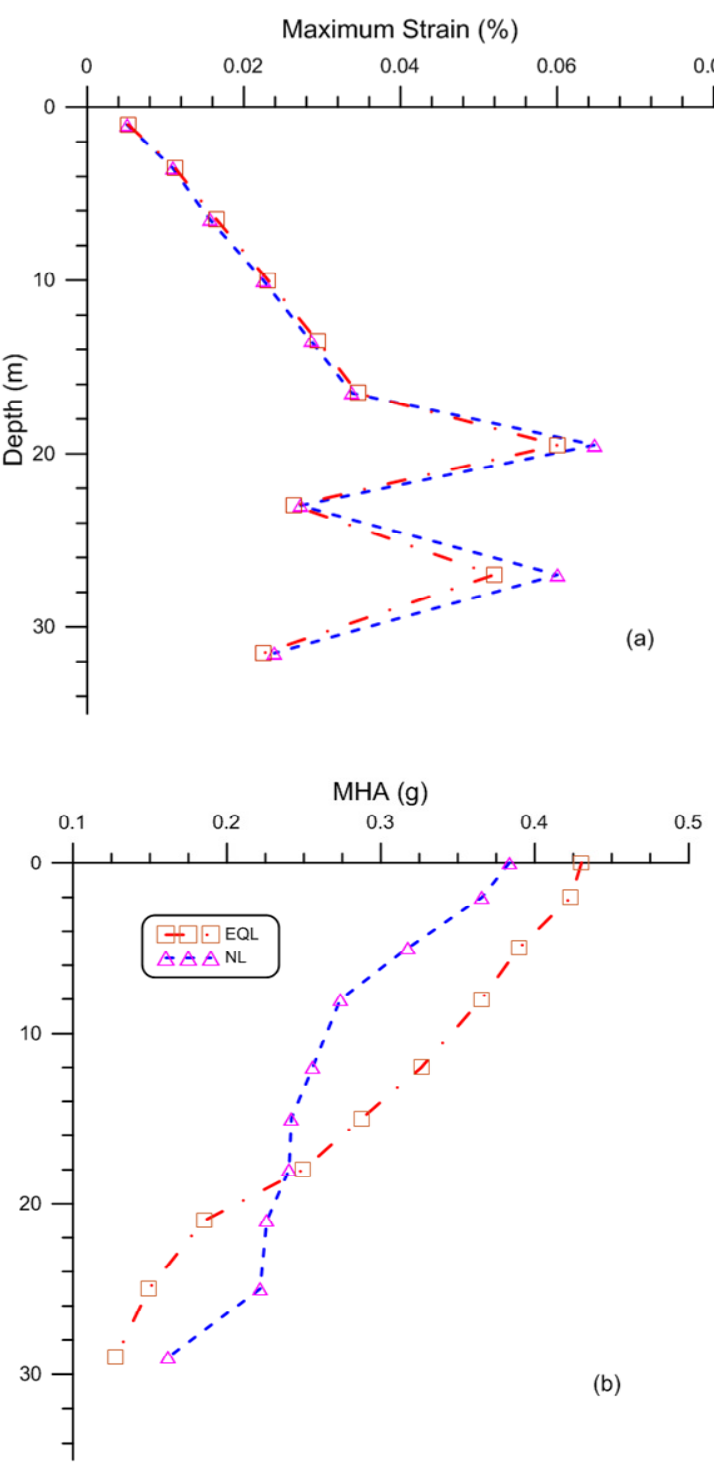

Figure 8. Results of NL and EQL Method Of Ground Response Analyses (a) Maximum Strain and (b) Maximum Horizontal Acceleration. 


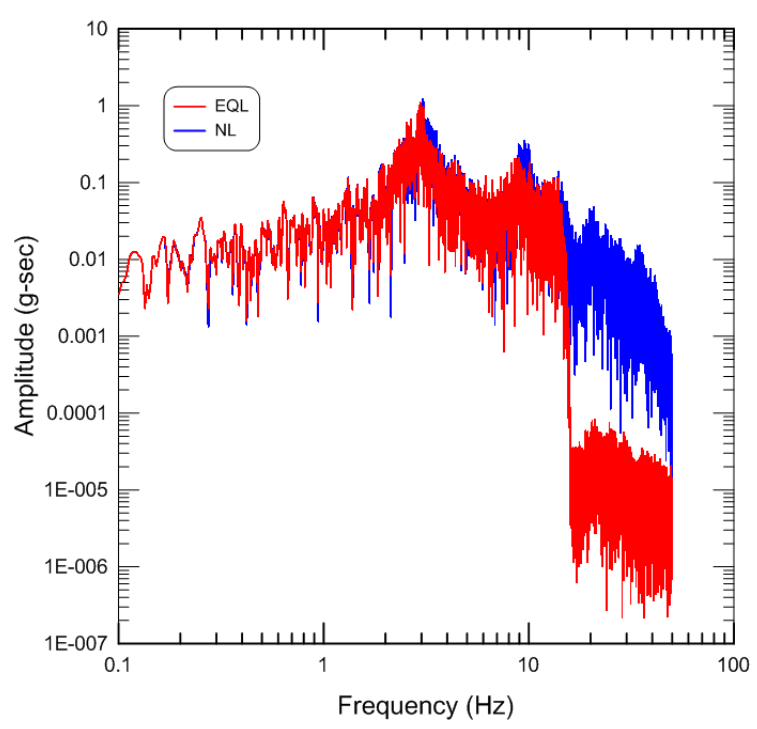

Figure 6. Fourier Transforms of The Surface Spectral Accelerations Subjected to Input Motions in EQL and NL Method.

other hand, NL method analyses utilize different shear modulus for each layer and may range from the low-strain to the highstrain shear modulus. Spectral acceleration in the higher frequencies is amplified and the continuous changing of soil properties (shear modulus) also excites the higher vibration modes. These modes are not captured in EQL method.

\section{CONCLUSION}

Ground response analysis of the WB site has been performed using PS Logging Test and Standard Penetration Test results. The soil profiles consist of a $34 \mathrm{~m}$ layer of clay, and granite thereafter. The shear wave velocity varies each layer. The EQL and NL ground response method was modelled with DeepSoil using dynamic soil properties and The Sumatra Earthquake, so called Sikuai2 with $\mathrm{Mw} 7.9$ in Sikuai Island, West Sumatra on September 12, 2007 as present input motion.

In general, results of the analyses with EQL method show similar trends to those with NL method. At surface layer, the acceleration values for EQL and NL methods are resulted as $0.425 \mathrm{~g}$ and $0.375 \mathrm{~g}$ respectively. When the ground response analyses show large-strain response, backbone curves should be adjusted to predict the shear strength at large strains. This correction will be needed for both method, either EQL method or NL method.
For research purposes in the future, we suggest to use local input motion so the ground response from analysis reflects the real condition of the site. NL method has a beneficial in term of capturing higher frequencies of spectral acceleration.

\section{ACKNOWLEDGEMENT}

This research was supported by the 2015 Research Fund of the KEPCO International Nuclear Graduate School (KINGS), Republic of Korea.

\section{REFERENCES}

[1] Y. M. A. Hashash, 2012. "Deepsoil," in Deepsoil v5.1, user manual and tutorial, pp. 1-107.

[2] C. Phillips, A. R. Kottke, Y. M. A. Hashash, and E. M. Rathje, 2012. "Significance of ground motion time step in one dimensional site response analysis," Soil Dyn. Earthq. Eng., vol. 43, pp. 202-217.

[3] Kramer, S.L.. 1996. Geotechnical Earthquake Engineering. Upper Saddle River. New Jersey: Prentice Hall.

[4] M. Papaspiliou, S. Kontoe, and J. J. Bommer, 2012. "An exploration of incorporating site response into PSHA - Part $I_{\Gamma}$ : Issues related to site response analysis methods," Soil Dyn. Earthq. Eng., vol. 42, pp. $302-315$.

[5] S. S. Kumar, P. Student, and A. M. Krishna, 2012 "Site-Specific Seismic Ground Response To Different Earthquake Motions," no. I, pp. 1061-1064.

[6] MonaLisa and S. Khan, 2013. "Equivalent linear earthquake site characterization of layered soil deposits at Shakardarra and Muzaffarabad," J. Himal. Earth Sci., vol. 46, no. 1, pp. 73-82.

[7] J. Kaklamanos, L. G. Baise, E. M. Thompson, and L. Dorfmann, 2015. "Comparison of 1D linear, equivalent-linear, and nonlinear site response models at six KiK-net validation sites," Soil Dyn. Earthq. Eng., vol. 69, pp. 207-219.

[8] Y. M. a Hashash and D. R. Groholski, 2010. "Recent advances in non-linear site response analysis," Fifth Interantional Conf. Recent Adv. Geotech. Earthq. Eng. Soil Dyn. Symp. Honor Profr. I.M. Idriss, vol. 29, no. 6, pp. 1-22.

[9] M. K. Effendi and E. Uckan, 2013. "True nonlinear seismic response analyses of soil deposits," Procedia Eng., vol. 54, pp. 387-400.

[10] K. Yee, E., Stewart, J.P., Tokimatsu, 2013. "Elastic and Large-Strain Nonlinear Seismic Site Response from Analysis of Vertical Array Recordings," J. Geotech. Geoenvirontmental Eng., vol. 139, no. 10, pp. 1789-1801.

[11] BATAN, "Final Topical Report Year 2: Geotechnical Investigations and Foundation Parameters of West Bangka”. Badan Tenaga Nuklir Nasional (BATAN), Jakarta, Indonesia, 2013.

[12] S. Khan, 2014. "Non-Linear Earthquake Response Spectrum Analysis of District Kotli, AJK with Increased Critical Damping Ratio,” Geodyn. Res. Int. Bull., no. 01, pp. XII-XXI. 
Halaman ini sengaja dikosongkan 